\title{
Strategy of Law Enforcement Against Fisheries Crime in Indonesia
}

\author{
Basri", M. Said Karim, ${ }^{* *}$ M. Djafar Saidi, ${ }^{* *}$ Syamsuddin Muchtar ${ }^{* * *}$ \\ *Doctoral Student, Faculty of Law, Hasanuddin University, Indonesia \\ ${ }^{* *}$ Professor, Faculty of Law, Hasanuddin University, Indonesia \\ ${ }^{* * *}$ Associate Professor, Faculty of Law, Hasanuddin University, Indonesia
}

\begin{abstract}
This study aims to find a law enforcement strategy against fisheries criminal offenses in Indonesia. This type of research used in this research is descriptive research. Analysis of the data used is quantitative. The results showed that the strategy of law enforcement in eradicating criminal acts of fisheries can be done by improving the licensing and supervision systems, applying criminal sanctions and involving the community, both in terms of planning and in terms of supervision. Law enforcement strategies can be realized well if supported by three ideal legal systems, namely the substance of the law itself, supported by the structure or law enforcement itself, and the culture of law in achieving good fisheries law enforcement.
\end{abstract}

Keywords: fisheries crime, Indonesia, law enforcement, strategy.

DOI: $10.7176 / \mathrm{IAGS} / 77-05$

Publication date: November $30^{\text {th }} 2019$

\section{Introduction}

The country of Indonesia is known as the largest archipelagic state in the world, having 17,499 islands from Sabang to Merauke. the total area reaches $5,455,675 \mathrm{~km}^{2}$, consisting of $1,910,931 \mathrm{~km}^{2}$ of land and $3,544,744 \mathrm{~km}^{2}$ or $2 / 3$ of which are waters or oceans, and 2,550,000 $\mathrm{km}^{2}$ of the Exclusive Economic Zone (EEZ). As a country with a greater water area than its land area, Indonesia is called a maritime country. ${ }^{1}$ Indonesia is a country that has a stretch of coastline with a length of $81,000 \mathrm{KM}$, thus making the Indonesian sea and Indonesia's coastal areas contain abundant wealth and natural marine biological resources, such as fish, coral reefs, mangrove forests and so on. A wide and rich marine species and fishing potential where in the area of catching 6.4 million tons/year and general fishery potential of 305,650 tons/year and marine potential of approximately 4 billion USD/year. ${ }^{2}$

As an archipelagic state, which was recognized by the United Nations Law Convention, the United Nations Convention on The Law of the Sea 1982 (UNCLOS 1982), began with the struggle for the concept of the archipelago's insight through a statement (declaration) concerning the territorial waters of Indonesia, announced by Prime Minister Djuanda Kartawidjaja on December 13, 1957. ${ }^{3}$

Some coastal areas in Indonesia have high potential and strategic fishing areas so that inevitably the main livelihood for the main community living in the coastal area is by going to sea (fishing). ${ }^{4}$ That all waters around, between and connecting islands or parts of islands which are included in the mainland of the Republic of Indonesia, irrespective of the width and width are reasonable parts of the mainland territory of the Republic of Indonesia, and as such are part rather than the national waters under absolute sovereignty of the Republic of Indonesia. Peaceful Lalulitas in these inland waters for foreign vessels is guaranteed as long as and does not conflict with the sovereignty and safety of the Indonesian state. The determination of the territorial sea boundary which is 12 miles wide measured from the lines connecting the outermost points on the islands of the Republic of Indonesia, will be determined by law.

\footnotetext{
${ }^{1}$ See https://kkp.go.id/artikel/2233-maritim-indonesia-kemewahan-yang-luar-biasa, downloaded April 21, 2019.

${ }^{2}$ Supridi and Alimudin, Hukum Perikanan di Indonesia, Jakarta: Sinar Grafika, 2001, p. 2; Sea is one of the sources of wealth of a country, because it saves natural resources very much, be it fish, seaweed, rocks, coral, and others. One of the lucky countries by the grace of the god associated with the marine area is Indonesia, See Abd. Asis, et.al., Strategic policy of the Government of Indonesia In the Field of Maritime and Fisheries Affairs, International Journal of Scientific and Research Publications, Volume 6, Issue 12, December 2016, p. 238

${ }^{3}$ Mochtar Kusumaatmadja, 1986, Hukum Laut Internasional, Bina Cipta, Jakarta, p. 186-187

4 Abd. Asis, et.al., Hak-Kewajiban Nelayan dan Kelompok Nelayan Menurut UU RI Nomor 7 Tahun 2016, Jurnal Hukum

“Justitia” Vol. V No. 1 September 2017, p. 53
} 
Mutual Benefit Principle in relations between countries requires that the subjects of international law (especially the state) in carrying out international relations be based on good faith so as to benefit all parties. ${ }^{1}$ The concept of the archipelago insight that began with the Djuanda Declaration was fought for in UNCLOS 1982 under the head of the Indonesian delegation Mochtar Kusumaatmadja, ${ }^{2}$ and on various occasions at international forums, diplomacy about the principles of this island nation is often conveyed. The principle of archipelagic insight is a very important principle for an archipelagic state, and Indonesia adheres to the principles of an archipelagic state, which at that time received great opposition from several countries, but thanks to the persistence of the Indonesian delegation, the concept of the archipelago insight was accepted in the international forum, so that now inter-island seas are also the territory of the Republic of Indonesia and not a free zone.

Geographically, the location of the Indonesian region occupies a strategic position between two continents, namely the Asian continent in the North and the Australian continent in the South, as well as two oceans, namely two oceans namely the Indian Ocean in the West and the Pacific Ocean in the East, placing itself in a position strategically in terms of economic, political, social, cultural and security defense, so it is very important for countries from various regions. This strategic position in addition to being an opportunity as well as a challenge in realizing the ideals of the nation, ${ }^{3}$ because besides having a beneficial impact at the same time it can also threaten the interests of Indonesia, causing complex problems, related to the field of security, law, economy and national defense. ${ }^{4}$

International law as the law governing its legal subjects (in many literatures it is mentioned that the subjects of international law include, state, international organitation, etc.). ${ }^{5}$ As an archipelagic country with a strategic position and has a large potential of fishery resources, it certainly attracts the attention of foreign fishing vessels to conduct illegal fishing (hereinafter referred to as fisheries criminal acts), both in the optics of national law and in optics of international law. In addition, other factors driving the occurrence of fisheries criminal offenses in Indonesia are the world's fish demand is increasing, on the other hand the world fish supply is declining, and there is an over demand especially fish species from the sea such as tuna. This is a significant contributor to the problem of decreasing fish stocks at sea. The rise of fisheries crimes is not only done by foreign-flagged vessels, but also often done by fishermen or domestic vessels, both those using modern fishing gear and those using traditional fishing gear.

The occurrence of fisheries criminal acts that are so massive, of course, affect state revenues in the export sector of marine fisheries, which in fact state revenues in the fisheries sector can contribute even more to the APBN revenue, thus helping to improve the welfare of the people, especially coastal people whose majority depend on their lives on making a living at sea. In addition, fishery crime can weaken the management of fisheries resources in Indonesian waters and cause fisheries resources in several Fisheries Management Areas of Indonesia to experience overfishing.

The economic potential of Indonesia's marine wealth is estimated at thousands of trillions, but has not yet been put to good use. As a comparison, in 2011 Indonesian fishery export data was only US \$ 3.34 billion, this amount is far less compared to Vietnam which recorded exports of US \$ 5.57 billion, even though the waters and length of the coastline owned by Vietnam are very small compared to Indonesia. The lack of Indonesian fishery exports was allegedly due to the rampant theft of fish in the Indonesian sea, so that the Jokowi government since mid-2014 took strict action against fisheries criminals, by sinking foreign vessels and domestic vessels conducting illegal fishing, and this has a positive impact because there was an increase in fish export revenues in 2016 reaching US \$ 3.59 billion $^{6}$ from US \$ 3.34 billion in 2011 . The rise of fish theft in the Indonesian sea has resulted in the state experiencing a loss predicted to reach Rp. 300 trillion per year. $^{7}$

\footnotetext{
${ }^{1}$ Kadarudin, Thamrin, H., Liao, I.-M., \& Satalak, P. (2019). Mutual Benefit Principle As Bilateral Basis of Indonesia With Thailand And Taiwan. International Journal of Global Community, 2(1 - March), 33-52. Retrieved from https://journal.riksawan.com/index.php/IJGC-RI/article/view/10

${ }^{2}$ Frans E. Likadja, 1985, Bunga Rampai Hukum Internasional, Bina Cipta, Bandung, p. 51

${ }^{3}$ Didik Heru Purnomo, Pengamanan Wilayah Laut Indonesia, Jurnal Hukum Internasional, December 2004, p. 2

${ }^{4}$ Ibid., p. 28

${ }^{5}$ Birkah Latif and Kadarudin, Pengantar Hukum Internasional, Makassar: Pustaka Pena Press, 2013, p. 39, see also Birkah Latif and Kadarudin, Hukum Perjanjian Internasional, Makassar: Pustaka Pena Press, 2013, p. 55

6 See https://suhana.web.id/2017/10/29/neraca perdagangan ikan 10 negara utama di dunia 2016/ downloaded January 1, 2019

${ }^{7}$ See http://presidenri.go.id/program-prioritas-2/memberantas-illegal-fishing-secara-tuntas.html downloaded September 29,
} 
The act of foreign ships entering Indonesian waters without permission and exploiting the natural wealth in them certainly violates the country's sovereignty. For this reason there must be strict law enforcement, in the form of arresting foreign vessels for legal processing. The act of catching a foreign vessel because it does not have a fishing business license (Surat Izin Usaha Penangkapan/SIUP) and a fishing permit license (Surat Izin Penangkapan Ikan/SIPI), as well as a fishing boat permit (Surat Izin Kapal Pengangkut Ikan/SIKPI) that is clearly capturing and/or transporting fish in Indonesian waters. ${ }^{1}$

In addition to foreign state vessels as stated above, fisheries criminal acts are also carried out by local fishermen, both those who use modern fishing gear and those who use traditional fishing gear, and the forms of palanggaran vary include fishing in the restricted zone, using fishing gear that is prohibited such as fish bombs, anesthesia, using ships that are not equipped with legal documents and other forms of violations. Based on the explanation, the problem that will be examined in this paper is how is the law enforcement strategy against fisheries crime in Indonesia?

\section{Research Method}

This type of research used in this research is prescriptive research, ${ }^{2}$ namely research that aims to provide an overview or formulate the problem in accordance with the circumstances/facts that exist. Analysis of the data used is qualitative.

\section{Results and Discussion}

Fisheries criminal act is a threat to the wealth of fisheries resources in Indonesian waters that are so broad and the impact is very detrimental to Indonesia, so that in order to maintain security as well as law enforcement in Indonesian territorial waters, a Maritime Security Coordination Agency (Bakorkamla) was formed through Presidential Regulation number 81 of 2005 The establishment of Bakamla is an effort to carry out sea security activities and operations carried out by government agencies in accordance with their main duties and functions as well as their respective authorities based on applicable laws and regulations. Article 3 states that the task of Bakorkamla is to coordinate the preparation of policies and the implementation of integrated marine security operations, consisting of the Indonesian National Navy (TNI AL), Water Police, the Ministry of Maritime Affairs and Fisheries (KKP). Bakorkamla is expected to be tasked with formulating policies and implementing integrated marine security operations, but in reality works in accordance with their respective laws and has not been coordinated. One of the obstacles of this institution is that the elements in this institution are still working sectorally, this also applies to institutional performance in the marine sector which tends to be ineffective, the purpose of ego-sectoral programs, and weak coordination between institutions. In addition, the complexity of the issue of management of marine resources is not balanced by increasing the capacity of adequate institutions and personnel, as well as public and implementing regulations and policies. The strategy of law enforcement against fisheries criminal offenses in Indonesia is as follows:

\section{A. Licensing and Development of Supervision Systems}

Being in the triangle area of the world's coral reefs, making the Indonesian sea rich in a variety of marine life such as fish and coral reefs. Not surprisingly, Indonesia is one of the largest fish producers in the world, including for reef fish species. As a strategic commodity, coral fishing is one of our fishermen's most engaged activities. ${ }^{3}$ One of the obstacles in the operation of each fishing boat is licensing matters. The fisheries licensing system so far has been in place and is running in Indonesia, but the existing system is in the context of giving permits or access to businesses to catch fish. Granting permission is one way to obtain state revenue. In the management of fisheries resources, licensing is a management mechanism, with the hope that utilization of resources will be regulated, entrepreneurs and fishermen will be governed by their accessibility. The permit system is used as a permit tool and gets money, so violations of the fisheries law are very likely to occur. Permits are issued as much as possible because in order to obtain a large income. The complexity of the existing

2018

${ }^{1}$ Sulasi Rohingati, 2014, Penenggelaman kapal Ikan Asing: Upaya Penegakan Hukum laut Indonesia, Pusat Pengkajian, Pengolahan Data dan Informasi Sekretariat Jenderal DPR RI, Jakarta, p. 2

${ }^{2}$ Bambang Waluyo, 2008, Penelitian Hukum dalam Praktek, Jakarta: Sinar Grafika, p. 9

${ }^{3}$ Abd. Asis, et.al., Persoalan Hukum Nelayan dan Kelompok Nelayan di Kabupaten Takalar, Jurnal Ilmu Hukum "The Juris" Vol. II No. 2 December 2018, p. 179; See also Munawir, Menilai Kepatuhan Nelayan Kabupaten Takalar dalam Perbaikan Perikanan Karang, WWF Indonesia, 2017, accessed at https://www.wwf.or.id/?54362/Evaluating-the-Fishermens-Level-ofCompliance-in-Takalar-Regency-in-Coral-Fishery-Improvement 
licensing system, as well as the many procedures that must be passed, all of these tend to create the possibility of misuse of permits and ultimately difficulties in monitoring fishing vessels scattered throughout Indonesia.

The rise of fisheries crime caught by law enforcement officers in Indonesia is generally related to licensing and licensing abuse. Permits that expire, conduct arrests that do not comply with permits, errors and differences in interpretation of the contents of the permit, as well as operations without permission are the types of IUU fisheries crimes encountered. This crime is generally in the perpetrators, but it is undeniable that this can be sourced from the weaknesses of the licensing system, including those responsible for the permit granting process. If the system is a process and the people responsible for falsifying this permit are weak, then the chances and possibility of a fishery crime will be very large. Revamping the licensing system is the first and strategic step in the war against IUU fisheries. If the licensing system for fisheries businesses can be truly carried out in accordance with the objectives of the development and management of fisheries resources, this will be a preventive measure for illegal fishing practices which will further facilitate supervision and control in the field.

In the Province of Southeast Sulawesi in terms of the management of fisheries business permits submitted by business actors through the Maluku Regional Investment Board (BPMD). Permits granted based on the Republic of Indonesia Maritime and Fisheries Ministerial Regulation Number 30/Men/2012 concerning capture fisheries business in the territory of the Republic of Indonesia, which is regulated in Chapter III about licensing in the first part about the types of permits and the validity period in Article 11 to Article 13. The second part is about the authority to issue permits in Article 14 to Article 15. The third part is about the requirements and procedures for issuing permits in paragraph 1 concerning Fishery Business Permit Article 16 to Article 18. Paragraph 2 Fishing Permit in Articles 19 to Article 23. Paragraph 3 concerning Fishing Vessel Permits in Article 24 to Article 28.

The licensing mechanism to date for fisheries business actors still raises in efficiency, this is because in the licensing process there are quite a lot of procedures that must be passed and felt difficult. Similarly, in terms of supervision. Oversight is also important in the war against the perpetrators of crime in fishing. Without supervision and control in the field, illegal fishing practices will become more widespread and difficult to control. The number of surveillance activities alone, even the practice of illegal fishing more and more. Moreover, if there is no supervision, there will be no arrests of illegal fishermen who cause deterrence. The success of supervision is very dependent on two main things, namely adequate monitoring equipment and human supervisors who understand their duties. These two things form a maximum monitoring system.

Monitoring vessels such as patrol boats are a must. The more patrol vessels, the more elements of supervision in the field. This is an important variable that influences the intentions of the perpetrators of illegal fishing. Some empirical studies reveal that if there is a patrol boat in the field, the perpetrators generally decide not to do illegal fishing. The presence of patrol boats in the field can prevent the crime of fishing. This is a reason for the government to increase its surveillance fleet equipped with tools that can detect fishing vessels at sea as well as the intensity of its operations in the field.

Supervision through satellite and electronic facilities known as Vessel Monitoring System (VMS) is recommended internationally. Through VMS, fishing vessels can be monitored for their movements and activities as long as they install and activate VMS transmitters on board. The intelligence of the VMS system, the behavior of fishermen and entrepreneurs who determine whether this system can run effectively. If a fisherman deliberately turns off the transmitter that has been installed, his activities will automatically not be detected at sea. Therefore, besides the reliability of the monitoring system on land and the transmitter itself, there needs to be clear rules and strict sanctions for those who deliberately do not operate VMS transmitters on board.

In addition to the surveillance system that involves law enforcement officers at sea, other monitoring patterns involve the community. Through this management pattern, fishermen are counted as part of the supervision itself. They can provide information or report on events that occur in fishing areas. They also used to take preventative measures and expel illegal fishing activities from Indonesian waters.

Successful supervision is very dependent on human resources. As sophisticated as any means of supervision, it will not be meaningful if human resources do not have the capacity and commitment to conduct supervision properly and according to rules. If those who are supposed to work as watchdogs are actually part of organized crime, illegal fishing itself, surveillance truly means nothing. Perpetrators of fisheries crimes are not afraid and respectful of supervisors, on the contrary they are harassing oversight institutions, especially harassing supervisors in the field. 
If a situation like this occurs that makes institutions and official oversight systems ineffective, the role of the community in supervision should be prioritized again. The fishing community, which is the core of the existing monitoring group, needs to be strengthened and its institutional development expanded to include nonservice communities who do have concerns about this. In this connection also, the public in a broader spectrum which also concerns the media and the press, need to unceasingly report about the practice of illegal fishing. By doing so, it is hoped that supervision will be more effective, transparent and effective tools in preventing illegal fishing practices.

\section{B. Policy in the Field of Fisheries}

Crime and punishment are interesting forms of law in every conversation. This is due to the nature, character and formulation that is constantly undergoing transformation, along with, in line with the development of society and technological progress as a form of scientific development. The rapid development of criminal acts cannot always be answered, overcome by a criminal system. As a result, infertility, crime or criminalization continues. Restless society and the state tend to lose its legitimacy, which in the end the act of judging itself (eigenrichting) as a form of protest against the weak law enforcement system.

Montesquieu states that a good form of legislation must endorse crime prevention rather than punishment. ${ }^{1}$ Efforts to tackle crime or crime are included in the framework of criminal policy, which is a rational effort from the community in tackling crime. ${ }^{2}$ Moeljatno's formulation indicates that criminal law is a set of rules governing 3 elements, namely rules regarding criminal acts, criminal liability and verbal process of law enforcement in the event of a crime. This element shows the relationship between material criminal law and formal criminal law, which means that violations of material criminal law will be meaningless without the establishment of formal criminal law (criminal procedural law). Vice versa, formal criminal law cannot function without violations of material criminal law norms (criminal acts). ${ }^{3}$ In determining a criminal act, the use of a penal policy, the politics of criminal law policy is as follows:

1. How criminal law is well formulated and provides guidance to legislators as legislators.

2. Application policies implemented by the judiciary.

3. The policy of implementing criminal law carried out by the government.

The DPR policy stage is a crucial stage for the following stages. Because when criminal legislation is made, the direction to be determined is determined, not criminalization. Criminalization as the process of determining a person's actions as a crime, in this case illegal fishing.

The policy to make good criminal law regulations cannot be separated from the purpose of crime prevention. Crime prevention is an effort to control crime within the limits of community tolerance. ${ }^{4}$ Crime management policies with criminal law are essentially part of criminal law enforcement policies. Therefore, criminal law politics is part of law enforcement. So the crime prevention policy through the making of criminal legislation is an integral part of social politics. Social politics can be interpreted as rational efforts to achieve the welfare of society and at the same time include community protection. ${ }^{5}$ Therefore every criminal law policy must pay attention:

1. In the formulation stage, namely the problem of determining what acts should be made a criminal offense.

2. The problem of determining what sanctions should be imposed on the perpetrators.

Fisheries Law No. 45 Year 2009 concerning Amendments to Law No. 31 Year 2004 concerning Fisheries contains the cumulative criminal threat in preventing and combating illegal fishing and the criminal

\footnotetext{
${ }^{1}$ Muhadar and Audyna Mayasari Muin, Kriminologi (Suatu Pengantar), Makassar: Pusat Kajian Media dan Sumber Belajar, LKPP Universitas Hasanuddin, 2016, p. 3; See also A.S. Alam, 2010, Pengantar Kriminologi, Makassar: Pustaka Refleksi Books, p. 10-11

${ }^{2}$ Sudarto, 1981, Hukum dan Hukum Pidana, Alumni, Bandung, p. 38

${ }^{3}$ Andi Sofyan and Nur Azisa, Hukum Pidana, Makassar: Pustaka Pena Press, 2016, p. 3

${ }^{4}$ Mardjono Reksodipuro, Hak Azasi Manusia Dalam Sistem Peradilan Pidana, Lembaga Kriminologi, Jakarta, p. 84

5 Barda Nawawi, 1996, Bunga Rampai Kebijakan Pidana, Penerbit Citra Aditya Bakti, Bandung, p. 29-30
} 
sanction of adhering to cumulative crime. However, the inclusion of cumulative criminal sanctions does not mean that this illegal fishing crime can be prevented and eradicated. In this case aside from strict law enforcement by law enforcement officers in the field of fisheries, the factors that give birth to and fertilize the occurrence of illegal fishing must be sought, prevented and eradicated (criminal policy). Without reviewing and reviewing, analyzing and overcoming the results of the penal policy in the fisheries law, this will not produce satisfactory results.

The policy of sinking and blasting dozens of foreign vessels carried out by the Ministry of Maritime Affairs and Fisheries (KKP) without going through this trial is indeed a state authority based on article 69 Paragraph (4) of Law Number 45 Year 2009 Amendment to Law Number 31 Year 2004 Concerning Fisheries which states, "In carrying out the functions as referred to in paragraph (1) fisheries investigators and/or supervisors can take special measures in the form of burning and/or sinking of foreign-flagged fishing vessels based on sufficient preliminary evidence".

This action is expected to have a significant effect on the rights of traditional fishing to get catches of fish with increasing weight, it is also expected to be able to increase the country's economic income through abundant fisheries and marine resources. However, this national legal policy must also pay attention to international law, because the problems faced are related to countries of origin of foreign ship owners which can also cause controversy from various parties. Indonesia as a country that has ratified UNCLOS has the authority and sovereignty to enforce laws relating to domestic interests in territorial waters bordering other countries, in efforts to enforce these laws Indonesia must harmonize legal provisions national provisions with international law. Based on Article 73 paragraph (4) of UNCLOS 1982 when a foreign ship is arrested or detained, a coastal country must immediately notify the flag state, through the appropriate channels, about the actions taken and regarding any sentence imposed.

Criminal law policy endeavoring or making formulating a good legislation in an effort to the effectiveness of development in the fishery sector. Criminal law policy in the field of fisheries is demanded to be able to regulate so that criminal law can be enforced concretely, so that a person is sentenced to criminal law. The formulation of the provisions of criminal acts in the fishery sector functions as a controller that provides various types of foundation in the criminal law system. The formulation policy in criminal law generally aims to provide a deterrent effect for perpetrators of criminal offenses in the field of fisheries. So that the existence of criminal threats set out in the fisheries laws and related laws, is expected to reduce the number of criminal acts.

The criminal justice system policy in an effort to tackle crimes in the field of fisheries has now undergone various changes, because criminal acts in the field of fisheries itself are experiencing rapid development. Criminal action in the field of fisheries is an obstacle to the management of marine resources, this is because the consequences of criminal actions in the field of fisheries are very detrimental to the country's finances. This condition encourages criminal law policy, especially in the field of fisheries, especially illegal fishing.

\section{Society Participation}

Indonesia as a country that is endowed with abundant marine and fisheries resources potential, has become one of the advantages in national development to improve people's welfare. However, it was realized that there were still activities that did not obey the rules in utilizing these resources. For this reason, supervision is present in order to ensure an orderly implementation of the applicable laws and regulations in the field of maritime affairs and fisheries. In terms of guarding the sovereignty of the management of marine and fisheries resources, of course through optimal supervision, law enforcement at sea, especially from foreign vessels carrying out illegal fishing will be better, then the Indonesian nation will be sovereign in managing its own marine resources and fisheries .

To achieve maximum supervision, it is carried out through a hard structure and soft structure approach, starting from upstream to downstream. The hard structure approach is carried out by examining licensing documents, monitoring the position and movement of fishing vessels using vessel monitoring system (VMS) facilities, conducting surveillance operations at sea both independently by the Directorate General of PSDKP or in collaboration with other law enforcement institutions TNI-AL, POLAIR, Indonesian Air Force, and others. The approach used is soft structure carried out through several efforts, including collaborating with various Ministries/Institutions, bilateral/international cooperation, ratification of international conventions, active in international organizations (such as RPOA). 
Community Participation Law enforcement in general is not always the right and obligation of law enforcement. Likewise, fisheries law enforcement is not monopolized by law enforcement. Crimes against illegal fishing are organized crime, so that the institutionalization of the community is very important to be developed by establishing a number of rights and obligations of the community. The rights of the community that must be considered include: the right to obtain information easily and transparently, the right to obtain fair and nondiscriminatory services, the right to obtain security guarantees and legal protection, the right to convey information responsibly. In addition, the community is also required to provide obligations that are as broad as possible in the prevention and eradication of criminal acts of fisheries, so that it is substantially mandated to support law enforcement.

For the eradication of fisheries criminal acts, it is also needed a trust factor of law enforcers which leads to moral ethics of law enforcers, which will be able to arouse people's motivation to participate. Social communication established between law enforcement and the community will create a working relationship (network) as one of the important information networks for the sake of effective law enforcement, as well as for social supervision, which in turn creates an institution for social control.

The existence of communities in coastal areas and outermost small islands has an important role for the supervision of the marine resources and fisheries (Sumber Daya Kelautan dan Perikanan/SDKP) waters throughout Indonesia. The presence of the community can help the supervision to be better and more beneficial to the community and also the coastal ecology, given the still limited Human Resources of SDKP supervision compared to the area of the sea that must be monitored. In order to involve the active role of the community in monitoring fish resources in accordance with Article 67 of Law No. 31 of 2004 concerning Fisheries, as amended by Law No.45 of 2009, the Directorate General of Maritime and Fisheries Resources Supervision (General Director of PSDKP) has developed Community-based supervision system (Siswasmas) through the formation of a community watchdog group (Pokmaswas) which until now has been spread throughout Indonesia. Previously, community involvement in the efforts to supervise marine and fisheries resources had been done for a long time through indigenous groups, but to further optimize community participation, the ministry of maritime affairs and fisheries organized their institutions to become Pokmaswas. Through this management pattern, fishermen are counted as part of the supervision itself.

Guidance for Pokmawas is carried out continuously through outreach activities and technical guidance, provision of assistance in monitoring facilities and infrastructure, and evaluation of Pokmawas at the regional and national levels. Supervision in the field of maritime affairs and fisheries faces considerable challenges. Limitations on the number of fisheries supervisory personnel, limited monitoring facilities are often inversely proportional to the number of illegal fishermen and offenders, both from outside and from within the country, so that Pokmaswas is needed to be an alternative problem solving that is expected to be able to help supervise marine and fisheries resources. The birth of Pokmaswas departs from the collective awareness that the level of active community participation is the key to successful SDKP supervision. In line with the vision of the Ministry of Maritime Affairs and Fisheries to realize Indonesia as the largest producer of marine fisheries products, the existence of SDKP supervision becomes very important.

Capture fisheries productivity as one of the instruments to achieve the vision of realizing Indonesia as the largest producer of marine fisheries products, is certainly difficult to achieve if Indonesian fish and seas are continuously plundered by illegal fishing, so intensive supervision is needed for the sustainability of marine resources for the next generation. will come. Considering such a large maritime area and a large number of islands, community participation is needed to participate in protecting waters as a national asset, it is necessary to establish Pokmaswas as a concrete effort of the Ministry of Maritime Affairs and Fisheries through the Directorate General of Maritime and Fisheries Resources Supervision.

Supervision in the field of fisheries is carried out on various activities in the utilization of marine and fishery resources related to illegal unreported and uregulated (IUU) fishing, destructive fishing, fisheries cultivation, processing and marketing of fishery products, coastal ecosystems, utilization of sea sand, coastal and islands small, water conservation area, so that the fisheries resources owned are not continuously plundered by foreign vessels. That awareness is stated in Law No. 45 of 2009 concerning Amendment to Law No. 31 of 2004 concerning Fisheries, Article 67 explicitly states that the community can be involved in assisting fisheries supervision. It was further explained that Pokmaswas was a supervisor at the field level consisting of elements of community leaders, religious leaders, NGOs, fishermen, fish farmers and other maritime communities.

To strengthen the community participation, the Ministry of Maritime Affairs and Fisheries issued Decree No.KEP.58/MEN/2001 concerning Procedures for the Implementation of Community Monitoring 
Systems in the management and utilization of Marine and Fisheries Resources, provides technical signs in the formation of Pokmaswas as part of the fisheries supervision system.

\section{Conclusion}

The strategy of law enforcement in eradicating fisheries criminal acts can be carried out by improving licensing and supervision systems, applying criminal sanctions and involving the community, both in terms of planning and in terms of supervision. Law enforcement strategies can be realized well if supported by three ideal legal systems, namely the substance of the law itself, supported by the structure or law enforcement itself, and the culture of law in achieving good fisheries law enforcement.

\section{References}

A.S. Alam, 2010, Pengantar Kriminologi, Makassar: Pustaka Refleksi Books.

Abd. Asis, et.al., Strategic policy of the Government of Indonesia In the Field of Maritime and Fisheries Affairs, International Journal of Scientific and Research Publications, Volume 6, Issue 12, December 2016, p. 238

Abd. Asis, et.al., Hak-Kewajiban Nelayan dan Kelompok Nelayan Menurut UU RI Nomor 7 Tahun 2016, Jurnal Hukum "Justitia" Vol. V No. 1 September 2017.

Abd. Asis, et.al., Persoalan Hukum Nelayan dan Kelompok Nelayan di Kabupaten Takalar, Jurnal Ilmu Hukum "The Juris" Vol. II No. 2 December 2018.

Andi Sofyan and Nur Azisa, Hukum Pidana, Makassar: Pustaka Pena Press, 2016.

Bambang Waluyo, 2008, Penelitian Hukum dalam Praktek, Jakarta: Sinar Grafika.

Barda Nawawi, 1996, Bunga Rampai Kebijakan Pidana, Penerbit Citra Aditya Bakti, Bandung.

Birkah Latif and Kadarudin, Pengantar Hukum Internasional, Makassar: Pustaka Pena Press, 2013.

Birkah Latif and Kadarudin, Hukum Perjanjian Internasional, Makassar: Pustaka Pena Press, 2013.

Didik Heru Purnomo, Pengamanan Wilayah Laut Indonesia, Jurnal Hukum Internasional, December 2004.

Frans E. Likadja, 1985, Bunga Rampai Hukum Internasional, Bina Cipta, Bandung.

https://kkp.go.id/artikel/2233-maritim-indonesia-kemewahan-yang-luar-biasa, downloaded April 21, 2019.

https://suhana.web.id/2017/10/29/neraca perdagangan ikan_10 negara utama di dunia 2016/ downloaded January 1, 2019

http://presidenri.go.id/program-prioritas-2/memberantas-illegal-fishing-secara-tuntas.html September 29, 2018

Kadarudin, Thamrin, H., Liao, I.-M., \& Satalak, P. (2019). Mutual Benefit Principle As Bilateral Basis of Indonesia With Thailand And Taiwan. International Journal of Global Community, 2(1 - March), 33-52. Retrieved from https://journal.riksawan.com/index.php/IJGC-RI/article/view/10

Mardjono Reksodipuro, Hak Azasi Manusia Dalam Sistem Peradilan Pidana, Lembaga Kriminologi, Jakarta.

Mochtar Kusumaatmadja, 1986, Hukum Laut Internasional, Bina Cipta, Jakarta.

Muhadar and Audyna Mayasari Muin, Kriminologi (Suatu Pengantar), Makassar: Pusat Kajian Media dan Sumber Belajar, LKPP Universitas Hasanuddin, 2016.

Munawir, Menilai Kepatuhan Nelayan Kabupaten Takalar dalam Perbaikan Perikanan Karang, WWF Indonesia, 2017, accessed at https://www.wwf.or.id/?54362/Evaluating-the-Fishermens-Level-of-Compliance-inTakalar-Regency-in-Coral-Fishery-Improvement 
Sulasi Rohingati, 2014, Penenggelaman kapal Ikan Asing: Upaya Penegakan Hukum laut Indonesia, Pusat Pengkajian, Pengolahan Data dan Informasi Sekretariat Jenderal DPR RI, Jakarta.

Supridi and Alimudin, Hukum Perikanan di Indonesia, Jakarta: Sinar Grafika, 2001.

Sudarto, 1981, Hukum dan Hukum Pidana, Alumni, Bandung. 